\title{
Znaczenie empirii jako podstawy wyjaśniania, prognozowania i praktyki w naukach społecznych
}

\section{The importance of empiricry as the basis for explaining, forecasting and practice in social sciences}

Stowa kluczowe: empiria, opis, wyjaśnianie, intuicja, intrepretacjonizm, realizm

Keywords: empiricry, description, explanation, intuition, interpretivism, realism

\begin{abstract}
Abstrakt: Rozważania przedstawione $w$ artykule stanowić maja impuls do refleksji nad fundamentami, na których opieraja się wspótczesne ustalenia naukowe. Celem podjętej analizy jest ukazanie wachlarza watpliwości dotyczacych dokładności i doskonatości wspótczesnych ustalen badawczych w naukach społecznych, a w szczególności $w$ dyscyplinie nauki o polityce. W rzeczywistości społecznej wcią̇ istnieje wiele ograniczeń zarówno po stronie człowieka jako podmiotu badającego rzeczywistość jak i niedoskonałości narzędzi, którymi sie postuguje. W artykule omówione zostaty postawy wobec naukowego sporu polegajacego na konfrontacji paradygmatu scjentystycznego, osadzonego na gruncie empiryzmu, pozytywizmu z postmodernistycznym interpretacjonizmem, usytuowanym $w$ ramach paradygmatu hermeneutycznego.
\end{abstract}

Abstract: The considerations presented in the article are to be an impulse to reflect on the foundations on which modern scientific discoveries are based. The aim of the analysis is to present a number of doubts as to the accuracy and perfection of contemporary research results in social sciences, in particular in the discipline of political science. In social reality

* ORCID ID: https://orcid.org/0000-0003-3572-3498, doktor habilitowany nauk społecznych w dyscyplinie nauki o polityce. Pracownik Katedry Socjologii Polityki i Marketingu Politycznego Wydziału Nauk Politycznych i Studiów Międzynarodowych Uniwersytetu Warszawskiego. Członek Polskiego Towarzystwa Nauk Politycznych. E-mail: s.kozlowski@uw.edu.pl 
there are still many limitations both on the part of the human being as the subject examining reality and the imperfections of the tools he uses. The article discusses attitudes towards scientific dispute consisting in the clash of the scientific paradigm based on empiricism and positivism with postmodern interpretivism within the hermeneutic paradigm will soon end.

\section{Wprowadzenie}

Tytułowe rozważania stanowić mają impuls na rzecz refleksji nad fundamentami, na których opierają się współczesne ustalenia naukowe. $\mathrm{Z}$ jednej strony mamy do czynienia z paradygmatem scjentystycznym, wyrosłym na gruncie empiryzmu i pozytywizmu, z drugiej zaś z coraz bardziej popularnym interpretacjonizmem, usytuowanym w ramach paradygmatu hermeneutycznego. Ten drugi stał się przedmiotem wyraźnej krytyki reprezentantów pierwszego, widzących w nim eklektyczny przejaw postmodernistycznego, rzekomego negowania prawdy. Negacja postmodernistycznego, „intuicyjnego” funkcjonowania w świecie nauki wyraża się przy tym w różnych formach. Obok rzeczowej krytyki, wskazującej na zagrożenia wynikające z subiektywizmu czy zaniżania kryteriów badawczych ${ }^{1}$, pojawiają się głosy o zabarwieniu pryncypialnym, formułujące zarzuty o negowanie przez postmodernistów wielowiekowej spuścizny, tradycji naukowej i fundamentalnego dziedzictwa. Formułowany jest przy tym także zarzut, że „postmodernistyczni autorzy doprowadzili do niebywatej polityzacji myślenia, nakłaniając nas do podejrzliwości $i$ do tropienia wszędzie struktur władzy"2. U niektórych krytyków uwidacznia się wyraźna dezaprobata połączona z emocjonalnie zabarwioną niechęcią i dyskredytacją. W swoich analizach chociażby Piotr Sztompka formułuje nawet opinię, że postmodernizm to „destrukcja naukowej socjologii” stanowiąca „dewiację myślową”, „anarchizm metodologiczny”4, przejaw „egoistycznego hedonizmu, obsesyjnej konsumpcji, kultu użycia”, a „zwolennicy postmodernizmu, całkiem paradoksalnie, chyba z jakiejś masochistycznej potrzeby, publikują swoje książki w seriach socjologicznych”. Zastanawiające wydaje się to przywiązanie większości środowiska

1 Zob. E. Gellner, Postmodernizm, rozum i religia, Warszawa 1997.

2 R. Legutko, Postmodernizm, http://www.omp.org.pl/stareomp/index9059.php (20.05.2020).

3 P. Sztompka, Socjologia. Analiza spoteczeństwa, Kraków 2003, s. 25.

4 Tamże, s. 299.

5 Tamże, s. 510.

6 Tamże, s. 632. 
naukowego do tradycyjnie pojmowanej empirii, w którym nie ma nawet cienia wątpliwości co do słuszności wykorzystywanej metodologii, obserwacji i doświadczeń. Celem niniejszej analizy nie jest zakwestionowanie empirii na rzecz opierania się na niepewnej intuicji, ale ukazanie pewnego wachlarza wątpliwości, co do dokładności i doskonałości współczesnych narzędzi badawczych, co pośrednio prowadzić ma do ostrożności w formułowaniu twierdzeń budowanych na przekonaniu posiadania wiedzy ostatecznej, pewnej i prawdziwej.

Nie chodzi tylko o dostrzeżenie takich zjawisk jak np. pośpiech w formułowaniu sądów i opinii, który towarzyszy dziś zarówno politykom jak i naukowcom, a jest wynikiem zmian gospodarczych i rozwoju massmediów poszukujących szybkich odpowiedzi na niejednokrotnie złożone pytania. Ważne wydaje się także ukazanie słabości człowieka (wraz z jego niedoskonałymi zmysłami) jako podmiotu badającego, a także słabości narzędzi jakimi się posługuje w celu dociekania prawdy. Człowiek, jako podmiot poznający rzeczywistość, poza bardzo rozwiniętym na tle innych ssaków mózgiem, wydaje się być istotą dość ubogo wyposażoną w możliwość zmysłowego odbierania bodźców zewnętrznych. Nasz wzrok, słuch, węch, smak i dotyk nie są imponująco rozwinięte na tle możliwości licznych zwierząt, nie mówiąc już o tym, że pewnych zmysłów (termicznego, magnetycznego, elektrycznego) w ogóle nie posiadamy. Zatem sensualizm, będący odmianą empiryzmu, nie wydaje się do końca pewnym podejściem do poznawania otaczającego nas świata. Człowiek swoje braki i słabości od tysiącleci oczywiście niweluje za pomocą coraz to bardziej udoskonalanych narzędzi i technik pozwalających np. lepiej i więcej widzieć (narzędzia optyczne, mikroskopy, teleskopy) czy słyszeć (aparatura akustyczna). Wciąż jednak nie zna wszystkich kolorów, kształtów i dźwięków. Nie jest też do końca pewien swoich zdolności analitycznych, prawidłowości pracy swojego mózgu, procesów które w nim zachodzą i zniekształceń informacji, które do niego docierają, co w śmieszny sposób obnaża chociażby popularna zabawa w „głuchy telefon”. Nie przeszkadza mu to wcale w wyciaganiu wniosków, w definiowaniu rzeczywistości i oznaczaniu swoimi ułomnymi etykietami elementów poznanego świata. Człowiek nawet pozwala sobie wciąż na stwierdzenia typu: „człowiek miarą wszechrzeczy” i wierzy, że potrafi ustalić to, co jest dla niego najlepsze. Nie tylko dla niego samego, ale i świata. $Z$ jakiegoś powodu wierzymy, że jednostka ludzka może racjonalnie decydować, wybierać władze, rządzić. A przecież jest to niejednokrotnie osoba, która nie potrafi znaleźć swojego miejsca na Ziemi, wybrać sobie właściwego zawodu, a nawet odpowiedniej żony czy męża na całe życie. Może warto, 
abyśmy czasem poczuli się zaniepokojeni tym, w czyich rękach jest nasz los jako rządzonych przez jednostki i grupy złożone z ludzi niepewnych, słabych, błądzących, nie mówiąc już o ludzkich urojeniach. Nie możemy też mieć pewności, że naukowcy są wolni od ludzkich słabości i adekwatnie dobierają narzędzia badawcze chcąc poznawać rzeczywistość.

Analizując, nawet pobieżnie, stan wiedzy i zakres osiągnięć społeczeństw historycznych niejednokrotnie z politowaniem kiwamy głowami nad błędami naszych przodków sprzed kilkuset lat, przekonanych na bazie swoich „gruntownych” obserwacji, że Ziemia jest płaska, a słońce krąży wokół niej. Dziś już wiemy, że nawet nie jest idealną kulą, ponieważ ma spłaszczone bieguny. Co jednak wiedzieć będziemy jako ludzkość za 1000 lat? Czy przyszłe pokolenia też będą z politowaniem oceniać nasze zacofanie badawcze? Doświadczenie historyczne wskazuje na to, że prawdopodobnie tak właśnie będzie.

\section{Uwarunkowania eksplanacji}

Jedną ze wspomnianych wcześniej trudności, wynikających z potrzeb rynkowych jest dążenie do szybkiego wyjaśniania, teoretyzowania, które siłą rzeczy może nie być dostatecznie ugruntowane w oparciu o rzeczowy proces deskrypcji. Deskryptywna (empiryczna, opisowa) funkcja nauki odpowiadająca na fundamentalne pytanie - „jak jest?”, ściśle warunkuje wnioskowanie mieszczące w ramach eksplanacyjnej funkcji nauki (wyjaśniającej, teoretycznej), odpowiadającej na pytanie „dlaczego”. Niedokładność pierwszej skutkuje możliwością wyciągnięcia niepełnych, a nawet fałszywych wniosków w drugiej. Deskrypcja jest tym, na czym dziś opierać się powinna każda profesjonalna opinia, porada czy teoria. Rzetelność, dokładność, trafność opisu ma znaczenie kluczowe dla stawiania diagnozy, prognozowania i formułowania zaleceń. Takie standardy znamy od najmłodszych lat życia, kiedy np. korzystamy z wizyty u lekarza. Zanim przepisze nam receptę, przeprowadzi z nami wywiad, dzięki któremu uzyska podstawowe informacje o dolegliwościach pacjenta, a jeśli będzie miał jeszcze wątpliwości, to dodatkowo skieruje nas na badania szczegółowe np. RTG. Dzięki takiemu procedowaniu uzyska możliwie najbardziej pełny obraz stanu zdrowia pacjenta. Podobnie postępuje téz każdy dowódca kierujący operacjami wojskowymi. Zanim wyprowadzi swoich żołnierzy na pole walki, wyśle zwiadowców, a ci przygotują raport, w którym opiszą sytuację, scharakteryzują warunki, ukształtowanie terenu, alokację i liczbę wojsk przeciwnika, stan jego uzbrojenia itp. Uzyskanie 
możliwie jak największej liczby precyzyjnych informacji ma kluczowe znaczenie dla oszacowania własnych szans i podjęcia strategicznej decyzji. Podobnie też jest w naukach społecznych, choć tu mamy do czynienia z wykorzystaniem nieco innych narzędzi. Chodzi téz o to, aby badacz możliwie jak najpełniej opisał obiekt swojego badania nie tylko widząc go wyizolowanym z otoczenia, ale także uwzględniając jego powiązania z otoczeniem. Tu pojawia się istotne pytanie, o to, jak zrobić dokładną „fotografię” tego, co badamy. Zapewne im więcej detali uchwycimy, typ większa będzie szansa na wyciąnnięcie prawidłowych wniosków. Opisywanie, nawet najbardziej dokładne badanych obiektów, co prawda jeszcze nie jest nauką, ale bez tego nauki nie można uprawiać. W środowisku badaczy zajmujących się naukami społecznymi krąży ciekawa anegdota na temat badań w jednej z miejscowości na południu Francji. Otóż miała ona wzbudzić zainteresowanie naukowców ze względu na wysoką wartość dodatniego przyrostu naturalnego związanego (współczynnik urodzeń) w porównaniu z innymi miejscowościami. Niektórzy naukowcy podejmowali pierwsze próby dociekań, poszukując uwarunkowań historycznych, gospodarczych, kulturowych itp., podczas gdy pojawił się tam też pewien badacz, o którym można śmiało powiedzieć, że robił to, co naukowcom czasem uszczypliwie się wypomina, a mianowicie dzielił przysłowiowy „włos na czworo”. Zadał sobie trud, aby opisać każdy szczegół, który napotkał w terenie, co ciekawe - nawet spisywał rozkłady jazdy pociągów. Okazało się, iz jego drobiazgowa deskrypcja ujawniła prozaiczną i dość zabawną przyczynę wysokiego współczynnika urodzeń, którą było to, że przez miejscowość w środku nocy przejeżdżał z wielkim hukiem pociag ekspresowy relacji Paryż-Marsylia, budząc mieszkańców. Reszty można się już domyślić. Opis o charakterze drobiazgowym i bardzo szczegółowym $\mathrm{w}$ istocie może nam pomóc zrozumieć nie tylko skomplikowane przyczyny i uwarunkowania zjawisk (paradoksalnie tych niepotrzebnie często wypatrujemy, realizując ambitne badania), ale właśnie pozornie błahych, ale istotnych i ważących. Podany wcześniej przykład częściowo koresponduje z przyczynami dodatniego przyrostu naturalnego w Polsce w okresie stanu wojennego, kiedy obywatele po prostu mieli trudności w opuszczaniu swoich mieszkań, a wszelkie aktywności towarzyskie były zawieszone.

Dysponujemy licznymi metodami i technikami wykorzystywanymi w badaniach społecznych. Mamy szeroką paletę wyboru pomiędzy badaniami ilościowymi i jakościowymi, możemy przeprowadzać obserwacje, eksperymenty, wywiady indywidualne i grupowe, ale wciąż pojawia się swoisty niedosyt, szczególnie gdy analizujemy np. sondaże przedwybor- 
cze realizowane przez różne ośrodki badawcze. Wyniki tych badań często różnią się pomiędzy sobą i niejednokrotnie są dalekie od wyników samych wyborów. Pomijając kwestie nierzetelności, przekupstwa i korupcji politycznej, warto zastanowić się nad wartością naukową badań dotyczących preferencji politycznych, ponieważ być może pokazują nam istniejące słabości naszych warsztatów badawczych. Rozbieżne wyniki, niejednokrotnie przekraczające poziom błędu statystycznego, wyraźnie wciąż potwierdzają, że tylko rzeczywiste wybory jednoznacznie dowodzą jaka jest wola obywateli. W ostatnich latach, szczególnie w okresie kampanii wyborczych w Polsce wraca dyskusja nad brakiem jednolitości i spójności metodologicznej badań, w szczególności sondaży przedwyborczych. Dodatkowo sami politycy niejednokrotnie wyrażają nieufność w stosunku do ich ustaleń, a przeciętni wyborcy, nie znający warsztatu badawczego, bywają częstokroć zdezorientowani. W 2013 r. Marcin Duma, ówczesny szef Instytutu Badania Opinii Homo Homini, w liście skierowanym do Organizacji Firm Badania Opinii i Rynku oraz Polskiego Towarzystwa Badaczy Rynku i Opinii zwrócił się z apelem o ujednolicenie metodologii badań realizowanych przez pracownie ${ }^{7}$. Apel ten jednak został skrytykowane przez liczące się instytuty badawcze, które podkreślały potrzebę zachowania wolności gospodarczej i naukowej na tym polu, wskazywały na różne sposoby formułowania i kontekst pytań w kwestionariuszach, rodzaje prób, odmienne metody przeprowadzania wywiadów, czas realizacji badania i wiele innych. Trudno rozsądzić, czy mamy do czynienia z pretekstami, czy realnymi powodami odrzucenia propozycji ujednolicenia metodologii. Jeśli jednak nauka ma ustalać prawdę, to akurat nauki społeczne w tym kontekście nie przyblizają nas do niej, pozostawiając duże pole niedopowiedzeń i interpretacji. W najlepszym wypadku, ujmując to w konwencji żartobliwej pokazują, że prawda na temat opinii społecznej jest względna, a to co wiemy o poglądach obywateli bywa zależne od zmiennych nastrojów, być może od pory dnia, w której zadaje im się pytania, pogody, nastroju ankietera, sposobu przeprowadzania rozmowy, skrępowania respondentów itp. Naukowa perspektywa nakazuje rozumieć różnorodne uwarunkowania i problemy metodologiczne, ale z drugiej strony mało przekonujące wydaje się niekiedy tłumaczenie różnic obliczeniowych przez ekspertów reprezentujących poszczególne pracownie w szczególności, kiedy mamy do czynienia z sondażem exit

7 K. Lisowski, Instytuty badania opinii niechętne ujednolicaniu metodologii, https://www.wirtualnemedia.pl/artykul/instytuty-badania-opinii-niechetne-ujednolicaniu-metodologii (25.05.2020). 
pool, a właśnie taka sytuacja zaistniała 26 maja 2019 r., w dniu wyborów do Parlamentu Europejskiego. Wyraźnie niedoszacowane wyniki Prawa i Sprawiedliwości oraz przeszacowane wyniki Konfederacji tłumaczono znacznym odsetkiem osób, które odmówiły udziału w badaniu ${ }^{8}$. Powstaje jednak pytanie - czy tego typu badania w ogóle mają sens, skoro tak bardzo obnażają słabości narzędzi badawczych, tym bardziej, że jednoznaczna weryfikacja następuje w ciągu zaledwie kilku godzin na podstawie oficjalnych wyników wyborów ogłaszanych przez Państwową Komisję Wyborczą.

Nie ma realnych możliwości, aby ujednolicić każdy typ badania, zarówno z punktu widzenia zastosowania adekwatnej metodologii jak i nakładów pracy, kosztów i czasu realizacji. Niektóre jednak udaje się przeprowadzić bardzo szybko na bazie prostych obserwacji, ale są też takie, na których wyniki trzeba czekać nawet kilkadziesiąt lat. Dotyczyć to może zarówno nauk przyrodniczych jak i społecznych. Również, jeśli chodzi o wyjaśnianie naukowe, to niektórych odpowiedzi można udzielać w błyskawicznym tempie, co zapewne jest atrakcyjne z punktu widzenia współczesnych oczekiwań mass-mediów. Jednakże wciąż niepisaną regułą profesjonalnego, rzetelnego podejścia naukowego jest rozciąnięcie wnioskowania w czasie tak, aby nie ogłaszać wyników badań zbyt pośpiesznie, bez uzyskania maksymalnej pewności. Nie należy lekceważyć doświadczeń wskazujących, że dłuższy czas prowadzenia badania ma pozytywny wpływ na wnioskowanie, ale nie jest to warunek decydujący o trafności wniosków w sposób automatyczny. Badać i obserwować można też wiele lat, a na końcu wyciągnąć nieprawdziwe wnioski. Zarządzanie czasem jest trudne na niwie politologicznej, ponieważ scena polityczna jest dynamiczna, znacznie więcej wydarzeń jest upublicznianych również dzięki nowoczesnym mediom, w tym społecznościowym i rozwojowi Internetu. Kilkadziesiąt lat temu politycy nie musieli szybko reagować na fakty i ścigać się z konkurencją o to, kto pierwszy wyda oświadczenie i zajmie stanowisko, a korzyścią takiego funkcjonowania był czas na zastanowienie się, skalkulowanie, przeprowadzenie konsultacji. Współcześnie ujawnienie medialne danego zdarzenia wywołuje natychmiastowe uaktywnienie swoistej licytacji wniosków i rozwiązań. W istocie nie ma dziś klimatu na filozofów, mędrców czy politycznych strategów. Zamiast myślenia stra-

8 Ekspert Ipsos tłumaczy, skąd taka różnica w sondażu exit poll. „13 proc. ludzi odmówiło udziału w ankiecie", https://www.wprost.pl/wybory-euro-2019/sondaze/10220367/ ekspert-ipsos-tlumaczy-skad-taka-roznica-w-sondazu-exit-poll-13-proc-ludzi-odmowiloudzialu-w-ankiecie.html (26.05.2020). 
tegicznego uwidacznia się za to bardziej doraźna kalkulacja taktyczna, której politycznymi reprezentantami są tzw. spin doktorzy i think tanki. Być może mamy do czynienia w tej dziedzinie z prawem KopernikaGreshama mówiącym o tym, że gorszy pieniądz wypiera z rynku lepszy. Współczesnym problemem i wyzwaniem wydaje się także uleganie populizmowi, nie tylko przez opozycję polityczną (co może być w pewnych granicach zrozumiałe), ale również przez stronę rządową, a to już może mieć poważniejsze konsekwencje praktyczne. Utrzymywanie tego typu tendencji podważa sens istnienia rządowych ośrodków badawczych i strategicznych, których profesjonalna praca jest lekceważona ze względu na potrzeby propagandowe oraz medialne próby kształtowania opinii publicznej. Jeśli rządzący przyjmują jako standard założenie, że zdanie ekspertów w danej dziedzinie to tylko niewiążąca opinia, to oznacza, że mamy do czynienia z lekceważeniem nauki, a szerzej i dosadniej rzecz ujmując $z$ negowaniem prawdy i rozumu.

Niezależnie od trudności o charakterze politycznym, powinnością ludzi nauki nie powinno być koniunkturalne przystosowywanie się, ale opieranie opinii na ugruntowanych teoriach i badaniach naukowych. Od 2015 r. w Polsce trwa ożywiona dyskusja, na temat tego, czy obowiązująca konstytucja jest łamana przez rządzących. Na tym polu można było odnotować przypadki zajmowania gremialnych stanowisk przez wydziały prawa znanych uczelni wyższych. Wydaje się, że stanowisko w tak kluczowych kwestiach systemowych powinny zajmować również ciała przedstawicielskie politologów. Tymczasem poza indywidualnymi komentarzami, trudno (poza nielicznymi wyjątkami) takie stanowiska odnotować. Czy to oznacza, że na gruncie nauki o polityce nie wypracowano metod i narzędzi badawczych pozwalających na stwierdzenie: czy naruszone zostały podstawy systemowe funkcjonowania państwa demokratycznego? Być może aktualna sytuacja jest właśnie swoistym testem na to, czy politologia jako nauka jest w praktyce przydatna i czy politolodzy jako środowisko potrafią zająć stanowisko ugruntowane na własnych badaniach naukowych. Trudne i bardziej narażone na błąd, wydaje się wyprowadzanie wnioskowania bez badań, wiedzy źródłowej i pozyskiwania danych. Aczkolwiek nie oznacza to, że takie wnioskowanie jest w ogóle niemożliwe. O właściwościach badanych obiektów możemy wnioskować nie tylko na podstawie dogłębnego poznania ich właściwości i mechanizmów, ale także na podstawie obserwacji w dłuższym przedziale czasowym. W tym kontekście autor niniejszego artykułu wyniósł dość ciekawe spostrzeżenie z dyskusji w instytucie mongolskiej medycyny tradycyjnej w Ułan-Bator, w której uczestniczył w 2005 r. jako 
przedstawiciel polskiego ministerstwa zdrowia. Otóż w trakcie rozmowy z jednym z profesorów kierujących instytutem, pojawiła się wątpliwość sformułowana przez jednego z polskich wiceministrów. Sprawa dotyczyła problemu dopuszczenia na polski rynek preparatów, których właściwości chemiczne nie są przebadane i nie znamy w świetle ustaleń współczesnej nauki „zachodniej” procesów w nich zachodzących. Mongolski profesor bardzo spokojnie i ciekawie odpowiedział na ten zarzut jednym zdaniem: „My też nie znamy, ale stosujemy te leki od przeszło 400 lat”. Krótko mówiąc wyraźnie pokazał, że nasza niewiedza (na obecnym etapie rozwoju nauki) nie musi być przeszkodą w działaniu praktycznym, które opieramy na długotrwałej obserwacji w wymiarze statystycznym.

Niekiedy nie mamy dokładnego opisu badanych obiektów i procesów, nie poznaliśmy ich cech i nie widzimy wyraźnego obrazu rzeczywistości. Tu pojawia się trudność polegająca na tym, jak przejść do eksplanacji, czyli wyjaśniać ${ }^{9}$ i odpowiadać na pytanie: „dlaczego”, (nie mówiąc już o wdrożeniu działań praktycznych, instrumentalnych) jeśli nie mamy jasnych ustaleń na poziomie deskryptywnym? Trudno jest wyobrazić sobie lekarza, który ocenia stan zdrowia pacjenta na podstawie pobieżnego wywiadu i nieczytelnego zdjęcia rentgenowskiego. Posiadanie dokładnych informacji w wymiarze deskryptywnym wciąż pozostaje istotnym i pożądanym warunkiem podjęcia profesjonalnego działania. Nie należy jednak z góry wykluczać procedowania w sytuacjach nadzwyczajnych i ekstremalnych (presja czasu, brak dostępnych źródeł informacji), w których paradoksalnie, niekiedy z sukcesem podejmujemy ryzyko oparte na intuicji i innych, nieadekwatnych doświadczeniach.

\section{Wykorzystanie $\mathrm{z}$ intuicji}

Zarówno w świecie polityki jak i nauki niekiedy mamy do czynienia ze swoistą nadzieją na skuteczność wykorzystania podejścia intuicyjnego. Według Macieja Dymkowskiego, analizującego problem działania intuicyjnego z punktu widzenia psychologa, ludzie nie posiadają na ogół trafnej wiedzy (szczególnie wiedzy o sobie), a jednak ostatecznie nierzadko wychodzą na tym dobrze ${ }^{10}$. Paradoksalnie brak pewnej wiedzy,

9 Więcej na temat rol wyjaśniania w rozumieniu działań i zjawisk politycznych zob. T. Klementewicz, Rola wyjaśniania $w$ rozumieniu działań $i$ zjawisk politycznych, «Studia Politologiczne» 2010, vol. 17.

10 M. Dymkowski, Między psychologia a historia. O roli złudzeń w dziejach, Warszawa 2000, s. 55 . 
w tym samowiedzy nie musi być przeszkodą w podejmowaniu trafnych decyzji. Praktykowanie realistycznego podejścia do samego siebie, może też przynosić mniejszy sukces niż oparte na fałszywych przeświadczeniach i iluzjach wyobrażenie własnej osoby, któremu może towarzyszyć większa odwaga i przebojowość. W historii też niejedno spektakularne odkrycie wiązało się z ryzykiem, determinacją i swoistą wiarą ambitnych odkrywców, lekceważących brak całkowitej wiedzy o gruncie, na który wchodzą. W podobnym kontekście rozpatrywać można sukces polskich przemian ustrojowych zainicjowanych w 1989 r. jako wypadkową złudzeń i błędnych wyobrażeń zarówno po stronie opozycyjnej jak i rządowej11. Zdaniem M. Dymkowskiego właśnie zniekształcone wyobrażenia i przekonania mogą być nie tylko istotną, ale nawet najważniejszą przyczyną procesów i zdarzeń ${ }^{12}$. Nie można bezwzględnie zaprzeczyć temu, że również błędne założenia naukowców, mogą stać się podłożem trafnych odkryć.

Jeden z ciekawszych, kontrowersyjnych poglądów na rolę intuicji zaprezentował niegdyś Karl Gustaw Jung, dostrzegając swoisty rodzaj inteligencji w procesach nieświadomych, a nawet uznając prymat intuicji przed rozumieniem świadomym ${ }^{13}$. Oceniając to z pozycji scjentystycznej powiedzielibyśmy, że jest ten pogląd przesadnie eksponuje zaufanie do działań wychodzących poza zdobytą wiedzę, rozum i świadomość. Prawdopodobnie grupą podatną na pokusę intuicyjnego działania wydają się być politycy, próbujący dotrzeć do wyborcy z nową, atrakcyjną ofertą, szczególnie w sytuacji, gdy nie dysponują badaniami opinii publicznej, a znajdują się w sytuacji niecodziennej, nadzwyczajnej. Historyczne przykłady sukcesów wybitnych przywódców jak np. Aleksander Wielki, Juliusz Cezar czy Napoleon Bonaparte stanowić mogą swoistą zachętę do poszukiwania rozwiązań niedostępnych na bazie dotychczasowych doświadczeń i analiz. Tym bardziej, że nasze działania oparte np. o ustalenia naukowe są osadzone w istocie w przeszłości. Niemożliwe jest dokładne prognozowanie zmian na scenie politycznej ze względu na zbyt dużą liczbą zmiennych, w tym incydenty, a nawet katastrofy, które mogą kompletnie przeorganizować scenę polityczną. W Polsce takim wydarzeniem była chociażby katastrofa smoleńska w 2010 r. Wywołała wówczas takie zmiany, jakich nie można było przewidzieć w ramach standardowego prognozowania. Być może jednak mętne przeczucia, urojenia i złu-

11 Tamże, s. 59.

12 Tamże, s. 65.

13 K.G. Jung, Rebis czyli kamień filozofów, Warszawa 1989, s. 239. 
dzenia sprzyjają osiągnieciu sukcesu w działaniu, mając paradoksalnie z naukowego punktu widzenia wątpliwe i niepewne podstawy. Zdaniem Z. Zaborowskiego zarówno iluzje upiększające i poprawiające rzeczywistość (wydarzenia i ludzi w odniesieniu do przeszłości, teraźniejszości, przyszłości) jak i złudzenia są ludziom potrzebne w niektórych okresach życiowych i sytuacjach ${ }^{14}$.

Warto postawić tu także pytanie o dopuszczalne granice działań i zachowań np. polityków, kierujących się złudzeniami i intuicją, skoro wykraczają poza znany wszystkim grunt. A skoro wchodzą na inne pole, to nie obowiązują już zasady właściwe w dotychczasowej grze politycznej. Znana sentencja łacińska Aleia iacta est, przypisywana Juliuszowi Cezarowi po przekroczeniu Rubikon obrazuje zmianę epokową, systemową, w tym przypadku demontaż republiki na rzecz tworzenia czegoś nowego, nieznanego jeszcze nikomu. Wcześniej zastosowanie nieznanych i niekonwencjonalnych metod zobrazował Aleksander Macedoński aktem przecięcia węzła gordyjskiego pokazując, że można rozwiązać problem nie wikłając się jego dogłębne poznawanie i drobiazgowe czynności. Podobnie przecież można rozpatrywać rewolucję amerykańską i tworzenie Stanów Zjednoczonych jako oryginalnego novum systemowego, opartego na mniej czy bardziej racjonalnych wyobrażeniach „ojców” założycieli.

Nie sposób zakwestionować związku pomiędzy rozwojem wiedzy a zmianami społecznymi zauważalnymi przecież w historii. W zbliżonym kontekście istotny problem dostrzegł Karl Popper podkreślając, że „przyszłego rozwoju wiedzy nie da się przewidzieć żadnymi racjonalnymi czy naukowymi metodami”15. Nie będziemy w stanie przewidywać $\mathrm{w}$ istocie biegu historii, co nie wyklucza wprawdzie prognozowania społecznego, ale pozbawia nas złudzeń co do możliwości urzeczywistniania tu i teraz tego, co przewidujemy. Niejednokrotnie naukowcy są publicznie krytykowani za brak trafnych diagnoz i niesprawdzające się przewidywania, ale badając coś z pewnej perspektywy, nie będąc w tym osobiście „zanurzonym”, trudno jest wszystko precyzyjnie przewidzieć. Podobne wrażenie sprawiają też piłkarscy komentatorzy sportowi, którzy oceniają zawodników po meczu i doskonale analizują ich błędy, ale przed meczem nierzadko mylą się w przewidywaniach. Nie można oczekiwać od politologa, żeby był dobrym politykiem, a polityk z kolei może być słabym politologiem, nawet jeśli posiada formalne wykształcenie w tej dyscyplinie. Podobnie kryminolog może nie mieć predyspozycji, żeby być

14 Z. Zaborowski, Świadomość i samoświadomość człowieka, Warszawa 1998, s. 199.

15 K.R. Popper, Nędza historycyzmu, Warszawa 1999, s. 10. 
sprawnym kryminalistą, tak jak kierowca rajdowy nie musi być dobrym instruktorem jazdy samochodem, nie mając talentu do nauczania innych.

Być może kierowanie się intuicją czy instynktem, jak to ma miejsce w przypadku zwierząt, bywa konieczne i przynosi w pewnej mierze pozytywne rezultaty. Niejednokrotnie przecież widzimy sarnę wybiegającą z lasu na drogę, a pomimo nieznajomości zasad ruchu drogowego i doświadczenia z samochodami w większości przypadków udaje jej się zrobić to bezkolizyjnie. Nie potrafimy jednak wyobrazić sobie, że tak mieliby postępować ludzie, a w szczególności naukowcy, od których wymaga się przeprowadzania dokładnych obserwacji, rzetelnych opisów, zweryfikowania wyników badań. Fałszywym wyobrażeniem o ludziach nauki jest jednak pogląd, że mogą oni w ogóle działać bez intuicji. $\mathrm{Na}$ etapie stawiania pytań, formułowania problemu badawczego i zainteresowania się czymś, korzystają ze swoich przeczuć - coś ich dziwi, intryguje, ciekawi. Zapewne na etapie stawiania pytań badawczych, takie podejście intuicyjne wydaje się bardziej dopuszczalne niż na etapie wnioskowania, co do którego oczekuje się czegós więcej niż przeczucie. Nie wyobrażamy sobie jednak, że moglibyśmy całkowicie funkcjonować w sposób intuicyjny, spontaniczny i bez przygotowywania się rozwiązywać wszystkie problemy. Gdyby postulat intuicyjnego działania miał powszechny charakter, to cały system edukacyjny zostałby podważony i uznany za niepotrzebny. Faktem trudnym do zakwestionowania jest jednak to, że paradoksalnie pozytywne przemiany społeczne zawdzięczamy niekiedy niewiedzy, bezmyślności i głupocie ${ }^{16}$. Nie wydaje się jednak, że powinniśmy czuć się ośmieleni, w szczególności działając na niwie naukowej, w beztroskim lekceważeniu doświadczenia naukowego.

$\mathrm{Na}$ ogół podejście intuicyjne kojarzone jest z jakościowymi metodami badań, jednakże Peter John twierdzi, że wykorzystanie intuicji nie jest wyłączną domeną badaczy stosujących metody jakościowe. W równym stopniu potrzebują jej naukowcy dokonujący pomiarów w ramach badań ilościowych ${ }^{17}$. Naukowe doświadczenie badaczy, ich intuicja i inteligencja powinny być wykorzystywane w pracy eksploracyjnej, co wiąże się też z wielowymiarową czujnością. Niekiedy warto jest brać pod uwagę pozornie nieistotne zmienne, które mimo wszystko mogą okazać się w jakiś sposób skorelowane.

16 M. Dymkowski, Między psychologia a historia..., s. 65.

17 P. John, Metody ilościowe, [w:] D. Marsh, G. Stoker (red.), Teorie i metody w naukach politycznych, Kraków 2006, s. 218-231. 
W przypadku współwystępowania wielu różnych zmiennych niekiedy istnieje trudność przy podejmowaniu próby zbadania ich istotności. Pewną pułapką może być zbyt pochopne wyciąganie związków przyczynowo-skutkowych, wskazujących na wynikanie jednej zmiennej z drugiej. Humorystycznie rzecz ujmując, dopatrywanie się związku pomiędzy przelotem bociana nad wsią, a faktem przyjścia na świat dziecka w tym samym miejscu nie jest najlepszym pomysłem na badania. Problematyczne dla realizacji badań natomiast może być, jeśli naprawdę wierzymy, że bociany przynoszą dzieci, bowiem banalny wniosek z korelacji dwóch zmiennych sam się nasuwa, a przekonania badającego mogą ukierunkowywać wnioski. Uproszczenia w analizie korelacji bywają bardzo atrakcyjne medialnie, dopuszcza się ich wiele środowisk zawodowych, nie mówiąc już o politykach chętnie widzących związek pomiędzy okresem ich rządów a wzrostem gospodarczym i nie baczących na to, że na wzrost gospodarczy mogły zapracować wcześniejsze rządy. Na problemy z analizą korelacji zwracają uwagę Elliot Aronson, Timothy Wilson i Robin Akert wskazując, że „metoda korelacyjna polega na systematycznym pomiarze dwóch zmiennych lub ich większej liczby i sprawdzaniu, czy są one ze sobą związane”18. Istnieć może dodatnia korelacja - wzrastanie jednej wartości następuje równolegle do wzrostu drugiej lub ujemna - wzrastanie wartości jednej zmiennej następuje równolegle ze spadkiem drugiej. Ważne zatem jest, aby nie wyciagać zbyt pochopnie wniosku o zależnościach, jeśli nie zgłębimy istoty relacji, ponieważ korelacja nie jest tożsama z przyczynowością, zaś „metoda korelacyjna mówi nam tylko, że dwie zmienne są ze sobą powiązane"19.

W obszarze badawczym politologii istnieją liczne pułapki związane ze zbyt pośpiesznym interpretowaniem charakteru korelacji i brakiem przeprowadzania gruntownych badań, w szczególności eksperymentów: „Krytycy zaznaczaja, że politolodzy, inaczej niż przedstawiciele nauk przyrodniczych, rzadko przeprowadzają eksperymenty, a zatem nie są w stanie ustalić, czy zaobserwowane przez nich na podstawie danych związki mają charakter przypadkowy, pozorny czy też przyczynowy”20. Wspomniani wcześniej autorzy podają przykład badań Leonarda Erona, w celu pokazania niejednoznaczności korelacji i przyczynowości. Badanie dotyczyło dwóch zmiennych: agresji u dzieci i oglądania przemocy w telewizji. Problem polega na tym, że na ogół wyciągamy prosty wniosek, że

18 E. Aronson, T. Wilson, R. Akert, Psychologia społeczna. Serce i umyst, Poznań 1997, s. 46.

19 Tamże, s. 50.

20 P. John, Metody ilościowe..., s. 225. 
przemoc oglądana w programach telewizyjnych prowadzi do niepożądanych, agresywnych zachowań u dzieci ${ }^{21}$. Paradoksalnie związek przyczynowy może być odwrotny, tj. agresywne dzieci mogą chętniej poszukiwać materiałów o przemocy i dlatego częściej oglądają w telewizji programy takiego typu. Oglądanie np. filmów o przemocy byłoby zatem skutkiem agresji a nie przyczyną. To jednak nie wszystkie warianty możliwych zależności. Jeśli wprowadzimy trzecią zmienną, którą jest negatywna postawa rodziców, zaniedbujących wychowywanie dzieci, można będzie wywieźć trzecią propozycję wnioskowania. Okaże się w tym wariancie, że dwie pierwsze zmienne należy traktować całościowo - agresja dzieci oraz oglądanie przemocy nie są wzajemnie powiązane, ale będą razem wynikiem zaniedbań wychowawczych, np. braku czasu rodziców na zajmowanie się nimi.

\section{Obiektywny opis a interpretacja}

Nie jest niczym niezwykłym to, że politycy funkcjonując w wyodrębnionych kręgach społecznych, żyją w swoistych „bańkach” informacyjnych i mogą być uwikłani w ukierunkowane postrzeganie rzeczywistości. Trudno w ich przypadku mówić o obiektywizmie w stosunku do „swoich” w porównaniu do „obcych”. Problematycznym jest obiektywny opis osób i zbiorowości, z którymi jesteśmy blisko związani, nie mówiąc już o obiektywnej ocenie. W szczególności jest to kłopotliwe dla naukowca próbującego obiektywnie opisać własne otoczenie. Spróbujmy wyobrazić sobie rodzica opisującego własne dzieci. Nawet jeśli wyraźnie podkreślamy, że oczekujemy tylko opisu a nie oceny, to możemy spodziewać się, że przedstawiony zostanie nam głównie zestaw cech pozytywnych i prezentowane będą one w pierwszej kolejności przed negatywnymi. Jeśli o opis poprosimy sąsiada rodziny, to może być dokładnie odwrotnie, jeśli np. jest to osoba przewrażliwiona na hałas, a dzieci są hałaśliwe, to w ich opisie ta kwestia może znaleźć się na pierwszym miejscu. Tu pojawia się swoisty dylemat, np.: czy o zwykły opis dzieci poprosić rodzica czy sąsiada. Zaletą pierwszego jest to, że lepiej zna dzieci, zaletą drugiego jest to, że nie ma z nimi bliskiego związku i obserwuje z zewnątrz. Wadą jednego jest to, że uczuciowa relacja z dziećmi może prowadzić do ukrywania cech negatywnych w opisie, wadą drugiego jest z kolei to,

21 Zob. L.D. Eron, Parent-child interaction, television violence, and aggression of children, «American Psychologist»1982, nr 37, s. 197-211. 
że będzie eksponować cechy, na które zwraca uwagę ze względu na swoje specyficzne potrzeby czy uprzedzenia. Wartość obydwu opisów ma wady i zalety. Być może dopiero syntetyczne zestawienie jednego i drugiego da nam punkt wyjścia do wnioskowania. Naukowiec także, niezależnie od swoich deklaracji i prób wyniesienia się na wyżyny obiektywizmu jest uwikłany w jakieś otoczenie społeczne i pewną rzeczywistość, która wpływa na to co robi, bada, jak bada i czym się w ogóle interesuje. Według Jana Szczepańskiego jednostka identyfikując się z określoną grupą ma tendencję do jej idealizowania, postrzegania jako lepszej od pozostałych, przeceniania jej prestiżu. Nawet historia narodu spisywana przez rodzimych historyków to obraz wyidealizowanej przeszłości, a prezentowana przez nich narracja nie jest $w$ istocie opisem, tylko zbiorem pewnych wyobra$\dot{z ̇ e n ́}^{22}$. Zwracał na to uwagę również Jerzy Topolski piszac: „Uczony jako (obiektywny lub subiektywny) członek takiej czy innej grupy społecznej akceptuje na ogół wyznawany przez ową grupę system wartości”23.

Według Ryszarda Podgórskiego opis naukowy nie polega wyłącznie na zarejestrowaniu danego faktu na zasadzie fotograficznego odbicia, ale powinien być interpretacją. W tym kontekście pokazuje on różnicę pomiędzy historią, która jest nauką i faktografią sprowadzającą się jedynie do rejestracji faktów ${ }^{24}$. Opis naukowy będący równocześnie interpretacją, prowadzi do wyjaśnienia lub zrozumienia faktu, w pewnym sensie zawierającego już jakieś zrozumienie czy wyjaśnienie ${ }^{25}$. R. Podgórski wymienia formy opisu rozumiejącego, wyjaśniającego, zawierającego już w sobie teorię rzeczywistości opisywanej:

1. strukturalny - wyróżniający elementy składowe opisywanego zjawiska i ukazujący na jakiej zasadzie stanowią one określoną całość;

2. funkcjonalny - podkreślający odniesienie zjawisk do pewnej całości, ukazujący sens w jakim opisywane zjawiska są warunkiem dla zachowania owej całości, a także sposób w jaki dane zjawiska dopełniają się wzajemnie w owej całości;

3. psychologiczny - prowadzący do pełniejszego, humanistycznego zrozumienia opisywanego faktu, zwracając uwagę na sprawcę, jego uwarunkowania wewnętrzne, psychologiczne i zewnętrzne - determinujące i motywujące, które stanowią całokształt okoliczności zaistnienia faktu czy zespołu faktów;

22 J. Szczepański, Elementarne pojęcia socjologii, Warszawa 1970, s. 268.

23 J. Topolski, Metodologia historii, Warszawa 1968, s. 232.

24 R.A. Podgórski, Metodologia badań socjologicznych. Kompendium wiedzy metodologicznej dla studentów, Bydgoszcz-Olsztyn 2007, s. 163. 
4. pragmatyczny - polegający na szeregowaniu faktów w takiej formie i porządku, aby ukazać sposób i przyczynę warunkowania jednych faktów przez inne, pokazujący jak jedne mogą być skutkami drugich, będąc ich społecznymi, psychologicznymi, czy funkcjonalnymi konsekwencjami;

5. wyjaśniający - polegający na poszukiwaniu bezpośrednich bądź pośrednich przyczyn zaistnienia zjawiska;

6. fenomenologiczny, istotowy - wskazujący istotne elementy badanego zjawiska, tj. elementy identyfikujące z jednej strony konkretnie zjawiska, a z drugiej umożliwiające odróżnienie ich od innych ${ }^{26}$.

Z kolei D. Marsh i P. Furlong, podkreślają, że stosunek wszystkich przedstawicieli nauk społecznych do badanego problemu zdeterminowany jest przez ich poglądy ontologiczne i epistemologiczne ${ }^{27}$. Dla podkreślenia tej specyfiki używają porównania skóry do swetra, wskazując, iż poglądy należy porównać do skóry, której nie można się pozbyć, choćby nawet dla zapewnienia sobie wygody. Pomimo że stanowisko epistemologiczne i ontologiczne są powiązane to D. Marsh i P. Furlong traktują je rozłącznie, aby ukazać jaki wpływ mają na poglądy politologów. Ontologia (dział filozofii zajmujący się teorią bytu) próbuje zbadać, czy istnieje rzeczywistość, która jest niezależna od naszej wiedzy w odniesieniu do niej. Ważne jest tu pytanie dotyczące tego, czy zjawiska społeczne należy pojmować przez ich obraz obiektywny i esencjalny, czy przez pryzmat kulturowych wzorców ${ }^{28}$. Istotny jest tu również dylemat występujący w naukach społecznych pomiędzy wyborem stanowiska naturalistycznego, które prowadziłoby do badań problemów w sposób właściwy dla nauk przyrodniczych a stanowiskiem o antynaturalistycznym profilu ${ }^{29}$. Na płaszczyźnie ontologii odzwierciedlają się poglądy badacza na naturę świata, zaś epistemologia pozwala dostrzec to, czego naukowiec może dowiedzieć się o świecie i jak to osiagnnąć. Wiążą się z tym pytania o to, czy obserwacje związków pomiędzy zjawiskami społecznymi są obiektywne i jak można ustalić te relacje. Naukowiec badający z pozycji antynaturalisty będzie widział relacje między zjawiskami, które nie mogą być wyłącznie obiektywne, ponieważ są postrzegane przez pryzmat określonego społeczeństwa. Z kolei naturalista uznawać będzie istnie-

26 Tamże, s. 164.

27 D. Marsh, P. Furlong, Skóra, a nie sweter: ontologia i epistemologia $w$ politologii, [w:] D. Marsh, G. Stoker (red.), Teorie i metody w naukach politycznych, Kraków 2006, s. 17-18. 28 Tamże, s. 18.

29 Tamże. 
nie rzeczywistości niezależnej jako sfery całkowicie zobiektywizowanej ${ }^{30}$. Cytowani autorzy zauważają istotne różnice w metodzie badania zjawisk. Kluczowe jest także pytanie, czy do badania zjawisk społecznych konieczny jest empiryzm, sensualizm, czy wystarczą czysto teoretyczne wyobrażenia ${ }^{31}$. Stanowisko naukowe - pozytywistyczne oraz hermeneutyczne - interpretacjonistyczne zwracają uwagę na inne aspekty. Pierwsze wymaga sformułowania generalizacji w celu wykrycia regularności i wydedukowania jakie ma to znaczenie dla kolejnego przypadku, po czym należy przeprowadzić obserwację pod kątem trafności prognozy - jeśli nie będzie trafna, to odrzuca się generalizację, albo koryguje i testuje nowe prognozy ${ }^{32}$. Tutaj opis zjawisk społecznych opiera się na wzorcu opisu zjawisk fizycznych, przyrodniczych i modelu przyjmowania hipotez, przeprowadzania doświadczeń oraz ewentualnego skorygowania tez, a istotne znaczenie ma wykrycie związków przyczynowych zachodzących pomiędzy zjawiskami o społecznym charakterze ${ }^{33}$.

Stanowisko hermeneutyczne, interpretacjonistyczne wymaga natomiast sięgnięcia do antynaturalistycznej tradycji badawczej, w której istotną rolę odgrywa rozumienie, znaczenie zjawisk, a nie ich objaśnianie. Ustalenie na tym gruncie występowania związków przyczynowo skutkowych między zjawiskami nie zawsze jest możliwe. Implikacje metodologiczne takiego stanowiska są dość jasne, a wynika z nich brak obiektywnej prawdy i przekonanie o społecznym konstruowaniu świata, zaś naukowcy (przedstawiciele nauk społecznych) mają badać te społeczne konstruk$\mathrm{cje}^{34}$. Interpretacjoniści uznają metody ilościowe za nieadekwatne instrumenty, mogące skutkować wytwarzaniem danych prowadzących do błędów. Za to chętniej sięgają do metod jakościowych, np. indywidualnych wywiadów pogłębionych czy zogniskowanych wywiadów grupowych, dających większą szansę na zbadanie sposobu rozumienia świata przez ludzi. Interpretacjoniści krytykowani są z pozycji pozytywistycznych za przedstawianie wyłącznie opinii ludzkich i subiektywnych poglądów, bez oparcia się o podstawę, dzięki której określone twierdzenia podlegałyby ocenie pod kątem ich obiektywnej słuszności.

30 Tamże, s. 19.

31 Tamże.

32 M. Hollis, S. Smith, Explaining and Understanding in International Relations, Oxford 1990, s. 50, za: D. Marsh, P. Furlong, Skóra, a nie sweter: ontologia i epistemologia w politologii..., s. 22.

33 D. Marsh, P. Furlong, Skóra, a nie sweter..., s. 22.

34 Tamże, s. 26. 
Spór pozytywistów i interpretacjonistów z biegiem lat wcale nie słabnie, a przybierając na sile, zdaje się wykraczać poza ramy stonowanej dyskusji akademickiej, co zostało pokrótce opisane na początku artykułu. Być może mamy na tym polu do czynienia ze swoistą dialektyką, która w historii nauki już nie raz występowała, a spór prowadził do wypracowania syntezy. Niewykluczone, że taką rolę odegra stanowisko realistyczne ${ }^{35}$. De facto główne idee tego stanowiska w klasycznej wersji są związane wyraźnie z koncepcjami Karola Marksa. W jego ramach występuje pozytywistyczne poszukiwanie związków przyczynowych pomiędzy zjawiskami, przy jednoczesnym unikaniu empiryzmu i badania wszystkiego przez doświadczenia bezpośrednie. Co prawda realizm i pozytywizm stoją na tym samym stanowisku ontologicznym, ale współcześnie realizm jest bliższy relatywizmowi w kategoriach epistemologicznych ${ }^{36}$. Stanowisko realistyczne uznaje istnienie świata obiektywnego, niezależnego od naszej wiedzy i prezentuje naturalistyczne podejście charakterystyczne dla pozytywistycznego, wraz z przyjmowaniem twierdzeń wskazujących na związki przyczynowe. Mimo to, brak jest w tym stanowisku uznania poglądu o możliwości bezpośredniego zaobserwowania wszystkich zjawisk społecznych i występujących związków. Realiści są przekonani o istnieniu, niemożliwych do obserwowania, ukrytych struktur ${ }^{37}$. Rzeczywistość pozornie widoczna "gołym” okiem może nas zwodzić za pomocą fałszywych fasad ukrywanej prawdy. Realizm dostrzegający dwoistość rzeczywistości i pozorów może być podejściem adekwatnym do badania gry interesów odbywających się w ramach określonych struktur. W ujęciu tym dopuszcza się pewną podejrzliwość badawczą. W rzeczywistości społecznej możemy mieć do czynienia z różnymi strukturami, grupami, kręgami np. biznesowymi, medialnymi, politycznymi, które ze względu na swoje korzyści są zainteresowane odwracaniem uwagi od spraw ważnych, na rzecz wyimaginowanych, wykreowanych doraźnie problemów, czy sztucznych konfliktów. W badaniach nie powinniśmy cechować się naiwnością, polegająca na bezkrytycznym przyjmowaniu informacji przekazywanych przez ludzi. Wyobraźmy sobie chociażby takie, problematyczne kwestie jak konkursy na wysokie stanowiska urzędnicze czy przetargi - w szczególności dotyczące wielomilionowych zamówien. Oficjalnie widzimy procedury, transparentne przepisy, prawidłowo zrealizowane konkursy, wszystko zgodne z prawem, ale ostatecznie okazuje

\footnotetext{
35 Tamże, s. 30.

36 Tamże.

37 Tamże.
} 
się, że w konkursie wygrywa osoba związana z rządzącym obozem politycznym, a przetarg wygrywa firma powiązana z wpływowymi politykami. Badając te kwestie w oparciu o podejście scjentystyczne odkryjemy, że wszystko odbyło się prawidłowo, zgodnie z prawem, wszyscy uczestnicy „zmowy” będą jednym głosem potwierdzać, że wygrał najlepszy. Nikomu nie jesteśmy w stanie udowodnić działania nieprawidłowego. $\mathrm{Na}$ gruncie realizmu badawczego nie będziemy skłonni ulegać takim iluzjom, a bardziej skupimy się na poszukiwaniu właściwości ukrytych, zakamuflowanych struktur, tworzących rzeczywistość obiektywną. Konstrukcja świata może być w obiektywnej rzeczywistości wytworem społecznym, wytworem podmiotowo działających ludzi, świadomych możliwości gry $\mathrm{z}$ „obiektywnym” systemem, przez co w istocie zmieniających jego właściwości, a nawet wypaczaja jego oficjalny charakter.

W kontekście struktur i podmiotowości ich uczestników warto zwrócić też uwagę na ujęcie dialektyczne, o czym pisze Stuart McAnulla: „Współcześni autorzy starają się przedstawić wizję, w której podkreśla się znaczenie zarówno struktury, jak i podmiotowości. Co więcej, wszyscy wypowiadają się również na temat związków i wzajemnych oddziaływań między strukturą a podmiotowością"38. W teorii strukturacji Anthony'ego Giddensa, uwidacznia się dynamiczne ujęcie struktury społecznej, wprowadzone wcześniej przez Norberta Eliasa ${ }^{39}$. Zdaniem A. Giddensa: „Konstytuowanie podmiotów i struktur to nie dwa niezależne od siebie ciagi zjawisk, lecz świadectwo dwoistości. Zgodnie z pojęciem dwoistości struktury właściwości strukturalne systemów społecznych są zarazem i nośnikiem, i wynikiem praktyk, które powtarzalnie organizują" 40 . Piotr Sztompka podjął się objaśnienia istoty takiego postrzegania struktur społecznych jako z jednej strony ograniczających, a z drugiej sprzyjających podmiotowemu działaniu uczestników systemu: „Istniejące struktury tworzą ramy, w których przebiegają ludzkie działania. W tym sensie istotnie wpływają na przebieg działań, stanowią czynnik współdeterminujący działania”41. Struktury są z jednej strony ogranicznikiem, a z drugiej stwarzają pewne szanse dla pewnej kreacji. Nie można zapomnieć téz o naukowej tradycji oddzielania struktury od podmiotowości uczestników. $\mathrm{Na}$ marginesie wspomnieć należy, że koncepcja A. Giddensa wywołuje wiele sporów i jest obiektem krytyki. $\mathrm{Na}$ polskim gruncie naukowym taką

\footnotetext{
38 S. McAnulla, Struktura a podmiotowość, [w:] D. Marsh, G. Stoker (red.), Teorie i metody w naukach politycznych, Kraków 2006, s. 280.

39 Zob. N. Elias, What is sociology?, London 1978.

40 A. Giddens, Stanowienie społeczeństwa. Zarys teorii strukturacji, Poznań 2003, s. 65.

41 P. Sztompka, Socjologia..., s. 145.
} 
krytykę podejmują m.in. Mirosława Marody i Anna Giza-Poleszczuk, zarzucające teorii A. Giddensa podtrzymywanie większości wad paradygmatu normatywnego i paradygmatu interpretatywnego ${ }^{42}$. Poszukiwanie nowych paradygmatów w nauce zawsze wywołuje spory, trudno jednak ocenić, czy w najbliższym czasie czeka nas przesilenie o syntetycznym charakterze.

\section{Podsumowanie: wiedza a rozumienie rzeczywistości}

Pomiędzy tym co wiemy i rozumiemy nie zawsze występują oczywiste związki. Niektórzy znani nam ludzie, mający nawet tytuły naukowe mogą imponować swoją rozległą wiedzą na niemal każdy temat. Zastanawiające jest to, dlaczego część z nich jedynie wie, ale nie rozumie istoty zjawisk i zachodzących procesów. $\mathrm{Z}$ pomocą w zobrazowaniu tego problemu przyjść może ciekawy przykład pomidora używany na wykładach przez niektórych psychologów. Otóż co wiemy na temat klasyfikacji naukowej pomidora? Wbrew niektórym obiegowym opiniom (kojarzącym pomidor z warzywem) klasyfikacja jest oczywista - pomidor zaliczamy do owoców. To wiemy? Rozumiemy jednak coś innego. Pomidora w sklepie spożywczym, wbrew naszej wiedzy, nie poszukujemy na dziale owocowym, ale intuicyjnie kierujemy się do działu warzywnego. A kiedy go już kupimy to nie wkrajamy do sałatki owocowej, tylko warzywnej. Jesteśmy zatem w pewnym sensie naukowo niekonsekwentni i nie postępujemy zgodnie z prawidłową klasyfikacją. Niemniej jednak działamy prawidłowo, w kontekście tego, jak powszechnie wykorzystywany jest ten owoc. Wykazujemy się czymś więcej niż wiedzą - kieruje nami rozumienie. Istotną rolę gra tu inteligencja i swoiste „wczucie się” w to co się wokół nas dzieje. Brak rozróżniania rozumienia i wiedzy skutkuje m.in. przemądrzałym wyśmiewaniem reguł stosowanych w Unii Europejskiej, np. w kwestii traktowania marchwi jako owocu, a nie warzywa. Jeśli jednak ktoś chciałby wyjść poza obręb dostępnej sobie wiedzy i wykazać się zrozumieniem, to dowiedziałby się, że w Portugalii produkuje się słodki dżem marchwiowy, a marchew pełni rolę owocu, co ma swoje gospodarcze i polityczne kon-

42 M. Marody, A. Giza-Poleszczuk, Przemiany więzi spotecznych. Zarys teorii zmiany społecznej, Warszawa 2004, s. 36; Krytycznie o teorii A. Giddensa piszą również: M.S. Archer, Realist Social Theory. The Morphogenetic Approach, Cambridge 1996; D. Layder, Modern Cocial Theory: Key Debates and New Directions, London 1997; M. Marody, Kulturowe aspekty zmiany społecznej, [w:] M. Marody (red.), Między rynkiem a etatem. Społeczne negocjowanie polskiej rzeczywistości, Warszawa 2000. 
sekwencje. Analizując niektóre raporty z badań można zauważyć, że ich autorzy nie zawsze znają specyfikę obiektów, które badają. Działają niejako z zewnątrz jako obcy i nie dostrzegają specyficznych kontekstów danego środowiska. Inni mogą być wybitnymi teoretykami, ale nie potrafiącymi ustalić jaka jest praktyka społeczna w badanym obszarze, bowiem nie współodczuwają tego samego, co członkowie badanej grupy.

Warto również zastanowić się nad tym jak opisywać zjawiska, które mają określoną specyfikę. Różne zjawiska społeczne możemy definiować chociażby w sposób statyczny albo dynamiczny. Niekiedy sam statyczny opis nie wystarczy, aby odzwierciedlić realnie istotę problemu. Pewne dziedziny mają wiele wymiarów dla funkcjonowania społecznego. Chociażby kultura może być definiowana na wiele sposobów, w pewnej mierze komplementarnych. Statyczny opis może być istotnym sposobem definiowania, ale niekoniecznie wystarczającym. Często cytowaną definicję kultury zaproponował niegdyś Edward Tylor, który w sposób deskryptywno-enumeratywny sprowadził definiowanie do przedstawienia elementów składowych jak: wiedza, wierzenia, sztuka, prawo, moralność, obyczaje ${ }^{43}$. Wydaje się to w pewnej mierze sensowne, że im więcej poszczególnych elementów składowych wymienimy w odniesieniu do badanego obiektu, tym bardziej zbliżamy się do jego prawidłowego zdefiniowania. Mimo wszystko powinniśmy uświadamiać sobie również przy użyciu intuicji, dla jakich obiektów takie definiowanie ma sens. Próbując przecież bezrefleksyjnie, w sposób opisowo-wyliczający zdefiniować człowieka można byłoby stwierdzić, iż człowiek to mózg, serce, nerki, wątroba, oczy, kończyny i inne elementy składowe. To nie oddaje istoty, społecznej roli i zrozumienia funkcjonowania człowieka. Brakuje tu dynamiki funkcjonowania i charakteru aktywności ludzkiej. Rozumienie rzeczywistości wydaje się niezbędne, chociażby w odniesieniu do prostej statystyki, wymagającej jednak inteligentnego rozróżniania podmiotów, których cechy chcemy wyszczególnić. W znanym dowcipie o statystyce jest mowa o tym, że statystycznie koń i jeździec mają po trzy nogi. Bazowanie na bezrefleksyjnych opisach statystycznych właśnie może prowadzić do takich wypaczeń we wnioskowaniu i przyczyniać się do powielania uproszczonych poglądów, że statystyka kłamie. Badając z wyczuciem, używając intuicji i doświadczenia mamy, być może, szansę na uniknięcie takich błędów. Nawet zwykłe badania ankietowe mogą nieraz utrudnić zrozumienie tego, co myślą respondenci wywo-

43 E.B. Tylor, Cywilizacja pierwotna, [w:] E. Nowicka (red.), Świat człowieka, świat kultury. Antologia tekstów klasycznej antropologii, Warszawa 2007, s. 82-96. 
dzący się z danego, konkretnego kręgu kulturowego albo danej grupy zawodowej. Niekiedy prosta odpowiedź respondenta mającego do wyboru opcję „tak”, „nie”, „nie mam zdania”, nie musi być odczytywana jednoznacznie. Jeśli zdajemy sobie sprawę, że są takie zbiorowości i kręgi społeczne, dla których w zwykłym słowie „nie” zawarta jest mniejsza bądź większa procentowo siła zaprzeczenia niż w języku używanym przez nas, to będziemy bardziej czujni przy wykorzystywaniu określonej metodologii. Gdybyśmy chcieli chociażby porównywać język dyplomatów do języka, którym posługują się przeciętni ludzie zauważylibyśmy np. większą ostrożność w używaniu sformułowań negatywnych. Trudno byłoby zrozumieć to, co naprawdę komunikują nam dyplomaci, gdybyśmy nie mieli już pewnych założeń w interpretowaniu ich słów. Podobnie trudności mogą występować w rozumieniu kontekstu wypowiedzi przedstawicieli innych narodów, ze względu na wpływy wynikające z tradycji i charakterystycznych doświadczeń historycznych, określanych niekiedy jako „duch narodu”. Współczesna nauka powinna uwzględniać szeroką paletę sposobów dochodzenia do prawdy, nie wykluczając przy tym nawet podejścia kazuistycznego, w ramach podejmowania prób rozumienia zjawisk społecznych. Naukowiec nie jest i nigdy nie będzie działał jak robot, mechanicznie i w sposób całkowicie zaprogramowany, ale wymyka się niekiedy z ustalonego systemu działania. Jednakże, gdy wychodzi poza znane mu konwencjonalne granice, powinien działać inteligentnie i być szczególnie czujnym.

\section{Bibliografia}

Archer M.S., Realist Social Theory. The Morphogenetic Approach, Cambridge 1996.

Aronson E., Wilson T., Akert R., Psychologia spoteczna. Serce i umyst, Poznań 1997.

Dymkowski M., Między psychologia a historia. O roli złudzeń w dziejach, Warszawa 2000.

Elias N., What is sociology?, London 1978.

Eron L.D., Parent-child interaction, television violence, and aggression of children, «American Psychologist» 1982, nr 37.

Gellner E., Postmodernizm, rozum i religia, Warszawa 1997.

Giddens A., Stanowienie społeczeństwa. Zarys teorii strukturacji, Poznań 2003.

Hollis M., Smith S., Explaining and Understanding in International Relations, Oxford 1990.

John J., Metody ilościowe, [w:] D. Marsh, G. Stoker (red.), Teorie i metody w naukach politycznych, Kraków 2006.

Jung K.G., Rebis czyli kamień filozofów, Warszawa 1989.

Klementewicz T., Rola wyjaśniania $w$ rozumieniu dziatań $i$ zjawisk politycznych, «Studia Politologiczne» 2010, vol. 17.

Kozłowski S., Rola deskrypcji w wiarygodnym wyjaśnianiu zjawisk społeczno-politycznych, „Studia Politologiczne” 2010, vol. 17.

Layder D., Modern Social Theory: Key Debates and New Directions, London 1997. 
Legutko R., Postmodernizm, Ośrodek Myśli Politycznej (20.05.2020).

Lisowski K., Instytuty badania opinii niechętne ujednolicaniu metodologii, https://www.wirtualnemedia.pl/artykul/instytuty-badania-opinii-niechetne-ujednolicaniu-metodologii, (25.05.2020).

Marody M., Giza-Poleszczuk A., Przemiany więzi społecznych. Zarys teorii zmiany spotecznej, Warszawa 2004.

Marody M., Kulturowe aspekty zmiany społecznej, [w:] M. Marody (red.), Między rynkiem a etatem. Spoteczne negocjowanie polskiej rzeczywistości, Warszawa 2000.

Marsh D., Furlong P., Skóra, a nie sweter: ontologia i epistemologia w politologii, [w:] D. Marsh, G. Stoker (red.), Teorie i metody w naukach politycznych, Kraków 2006.

McAnulla S., Struktura a podmiotowość, [w:] D. Marsh, G. Stoker (red.), Teorie i metody w naukach politycznych, Kraków 2006.

Podgórski R.A., Metodologia badań socjologicznych. Kompendium wiedzy metodologicznej dla studentów, Bydgoszcz-Olsztyn 2007.

Popper K.R., Nędza historycyzmu, Warszawa 1999.

Szczepański J., Elementarne pojęcia socjologii, Warszawa 1970.

Sztompka P., Socjologia. Analiza społeczeństwa, Kraków 2003.

Topolski J., Metodologia historii, Warszawa 1968.

Tylor E.B., Cywilizacja pierwotna, [w:] E. Nowicka (red.), Świat człowieka, świat kultury. Antologia tekstów klasycznej antropologii, Warszawa 2007.

Zaborowski Z., Świadomość i samoświadomość człowieka, Warszawa 1998. 